\title{
各種建物形状による超々高層建物の空力特性変化 Aerodynamic Characteristics of Super Tall Buildings with Unconventional Configurations
}

\section{1.まえがき}

2008 年のリーマンショック以降，世界最高高さ $828 \mathrm{~m}$ の超々高層建物である Burj Khalifa の建設計画が危ぶま れるなどのニュースがあり，世界の超々高層建物の建設 ラッシュに陰りが垣間見えたが，近年の超高層建物の高 層化にはやはり目を見張るものがある。高層化が顕著に 表れている数值としては，建物高さが $300 \mathrm{~m}$ 以上の建物 の竣工数が挙げられる。2010 年 1 月時点において，その

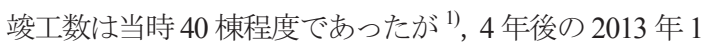
月時点において, その数は 80 棟以上に倍増している。ち なみに日本で $300 \mathrm{~m}$ 以上の超高層建物は，2014 年に竣工 予定のあべのハルカスが初となる。このような高層化の 一方で，世界の建物高さの上位 100 棟の建物形状にも注 目してみると, 正方形角柱や長方形角柱といった整形な 建物は，5\%に満たず，建物隅角部形状に工夫を加えた建 物が $25 \%$ ，その他，建物の水平断面が複雑なものや高さ 方向に断面が変化しているものなど，不整形な建物が残 りの 70\%を占めている(2010 年 1 月時点の建物諸元調査 結果 ${ }^{1)}$ 力ら大まかに分類)。このような不整形な建物形状 は，建物高さが高いものほど多い傾向にあり，前述の高 層化と相まって, 不整形で独創的な形状の超高層建物が, 都市のランドマーク・アイコン(象徴, シンボル)として の役割を担って増加している。そこには，建築意匠的な
面白さや美しさだけではなく，風に対する空気力学的な 合理性もある。それは，不整形な建物形状が，その空力 特性の優位性によって風荷重を低減できる点にあり，風 荷重が支配的となる超々高層建物において，その建物形 状による風荷重の低減効果は，安全性や経済性に大きな 影響を与える。風荷重を低減するために空力特性を改善 する手法の有効性は，これまで多くの文献によって示さ れてきており，建物隅角部形状の形状パラメーターを変 化させるなどした研究事例は多い。しかし，形状の異な る多数の建物形状間でその空力特性が統一的に比較され た研究事例はこれまでなく,「どの建物形状が風に対して より有利なのか?」との問いに答えることは難しかった。 そこで, 国土交通省・建設技術研究開発費(平成 20 年度, 21 年度)の補助を受け, 東京工芸大学, 竹中工務店, 鹿 島建設，日建設計，日本設計による共同研究として，複 数の異なる建物形状間で空力特性が比較され，耐風設計 上の優位性が評価された ${ }^{1)}$ 。この研究は，その後も科学 技術振興機構- 戦略的国際科学技術協力推進事業(日中研 究交流) (平成 22 年度〜 24 年度)として, 国際的な共同研 究に発展している。

本稿では，この共同研究の成果の一部 2) 4)を紹介する とともに，建物形状の変化による周囲の気流性状の変化 についても簡単に触れる。

\footnotetext{
* 1 株式会社竹中工務店 技術研究所 研究主任

Associate Chief Researcher, Takenaka Research \& Development Institute, Takenaka Corporation

*2 東京工芸大学 工学部 建築学科 教授

Professor, Department of Architecture, Tokyo Polytechnic University

* 3 ソウル科学技術大学 工学部建築学科 (建築学専攻) Lecturer

Lecturer, School of Architecture (Architecture Program), Seoul National University of Science and Technology
} 
2. 建物形状による空力特性の変化

2. 1 風力低減に効果のある建物形状

風力の低減に有効な建物形状としては, 多角形やクロ

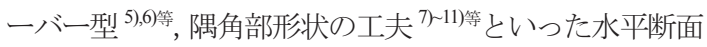
を変化させた建物形状の事例の他，尖塔形状 ${ }^{12}$-15)等やセ ットバック 14),15)等のように高さ方向に断面を絞った先細 りの形状, 開口の設置9),17等など建物形状を大きく変化さ せた事例まで多岐にわたっている。中でも隅角部形状を 工夫した研究事例は多く, 実際の建物にも多く見られる 隅角部形状の例としては, 面取り, 切欠き, 隅丸などが ある。風力の低減に効果のある面取りや切欠きのサイズ としては, 建物幅の $10 \%$ 程度で十分な効果が得られてい る 7),10,11)。また, 最近では, テーパーを設けた形状やセ ットバックなどの尖塔形状についての研究事例も増えて きており, 底面と頂面の幅の差を建物高さで除して算出 したテーパー率が 5〜10\%の範囲では, テーパー率が大 きいほど空力特性は良い傾向にある ${ }^{15)}$ 。開口を有寸る建 物形状の研究事例では, 壁面中央部に開口を設ける場合, 1 方向にだけ設けるよりも, 風方向と風直交方向の 2 方 向に設けるほうが空力特性は良い ${ }^{9,17}$ 。

\section{2 複数の建物形状間の空力特性の比較}

共同研究 1)では, 既に竣工した建物や計画中の建物の 中から不整形な形状を有する建物をピックアップしてい くつかのカテゴリーに形状を分類している。これらの分
類結果と 2.1 で示した既往の研究事例を参考に選定さ れた 30 体以上の建物形状が風洞実験の対象とされた。

図 1 は, 基本形状を高さ $400 \mathrm{~m}$, 幅 $50 \mathrm{~m}$ の正方形角柱(1) Square)として, 建物の高さと容積が同じという条件下で 複数の建物形状の最大変動風力係数(全風向中で最大の 変動風力係数(標淮偏差))を比較したものである。この変 動風力係数は風応答に大きく関係しており, 特に風直交 方向の変動風力係数が重要である。図中の 2 本の横線は, (1)Square の風直交方向の最大変動風力係数(上) と風方向 の最大変動風力係数(下)に相当しており, これらの横線 よりも棒グラフが下であれば, 正方形角柱より空力特性 が優れていることを示す。

図 1 で比較されている建物形状は, (1)Square の他, 長 方形, 三角形, 円, 楕円といった整形な建物形状(2)～(5)) と隅角部を工夫した形状(6)〜 (8)), 開口を設けた形状(10) 〜15), 傾いた形状(16), (17)), 尖塔形状を含む錐形状(18)〜 (22)), 螺旋形状(23)〜31)などである。また, これらの単一 の形状要素を複数組み合わせた複合形状(32) (35)にいい ても比較が行われている。ただし，曲面を有する形状(4) Circular と(5)Elliptic, (311 $180^{\circ}$ Helical Elliptic)については, 実構造物との対応を考える場合, レイノルズ数の影響を 考慮する必要があるため, 図中の值は参考值としての意 味合いが強い。なお, (4) Circularの直径を基準長さとした 風洞実験スケールのレイノルズ数は $R_{e}=2.9 \times 10^{4}$ である。

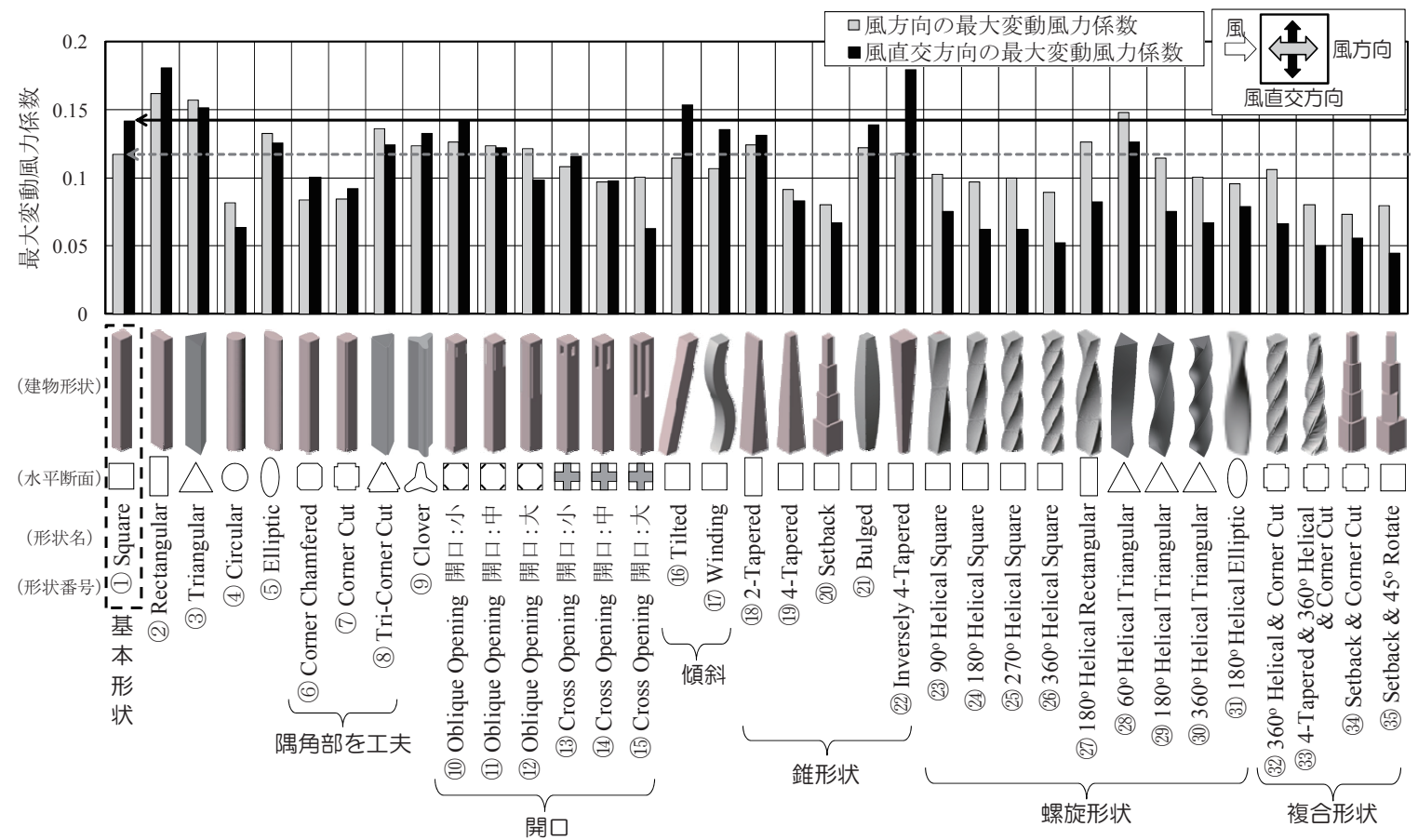

図 1 様々な建物形状の最大変動風力係数の比較 
図 1 より, 面取り(6)Corner Chamfered)や切欠き(7) Corner Cut)といった隅角部のわずかな形状変化が風力の 低減に大きな効果をもたらすことがわかるが，4 面にテ ーパーを設けた形状(19)4-Tapered)やセットバック(20) Setback), 螺旋形状(23)〜(26)Helical Square)などは, 風直交 方向に対してさらに優れた特性を示している。ちなみに,

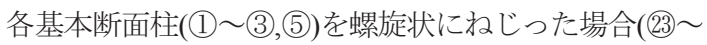
(31)), 図 2 の正方形断面と三角形断面の変化を見る限り, ねじれ角度が大きいほど効果は高いが，ねじれ角度を $180^{\circ}$ 以上にしても空力特性は大きくは変わらないようで

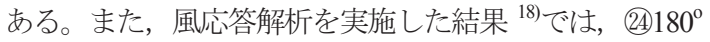
Helical Square $の$ 設計用風荷重は(1)Square $の 7$ 割以下とな る。長方形角柱(2)Rectangular)や三角柱(3)Triangular)の空 力特性は, (1)Squareよりも悪化するが，切久きを設けた 形状(8)Tri-Corner Cut)や螺旋形状(27)Helical Rectangular, (28) (30Helical Triangular)とすることで, 風直交方向の空力 特性は(1)Square よりもやや良くなる。複合形状(32)～(35) では, 他の形状よりも值が小さく, 単一の形状要素の場 合よりも総じて空力特性が良くなることがわかる。なお, 図 1 の風方向と風直交方向の最大変動風力係数の形状に よる変化を比較すると, 図 3 に示すように, これらは最 大值を示す風向が異なっていても概ね相関しており, 風 方向風力が小さい建物形状は, 風直交方向風力も小さい

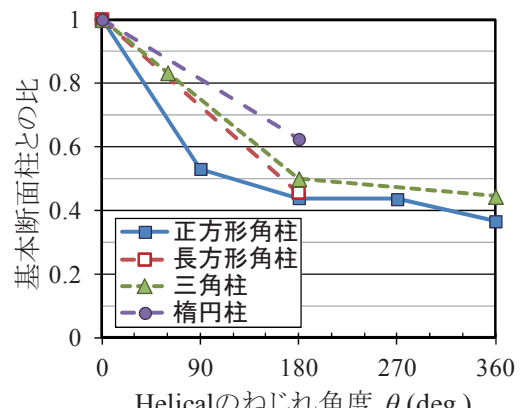

図 2 ねじれ角度による風直交方向変動風力係数の変化

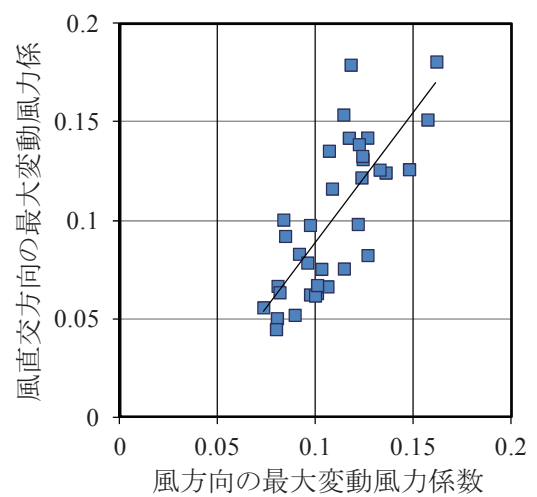

図 3 風方向亡風直交方向の変動風力係数の相関
ことが示唆される。また，この最大変動風力係数は最大 平均風力係数やパワースペクトル密度のピーク值の最大 值とも高い相関を持ち，とても興味深い結果と言える。

\section{3. 建物形状による渦放出性状の変化}

4 つの建物形状(1)Square, (7)Corner Cut, (20)Setback, (24) $180^{\circ}$ Helical Square $の$ 風直交方向の層風力係数のパワース

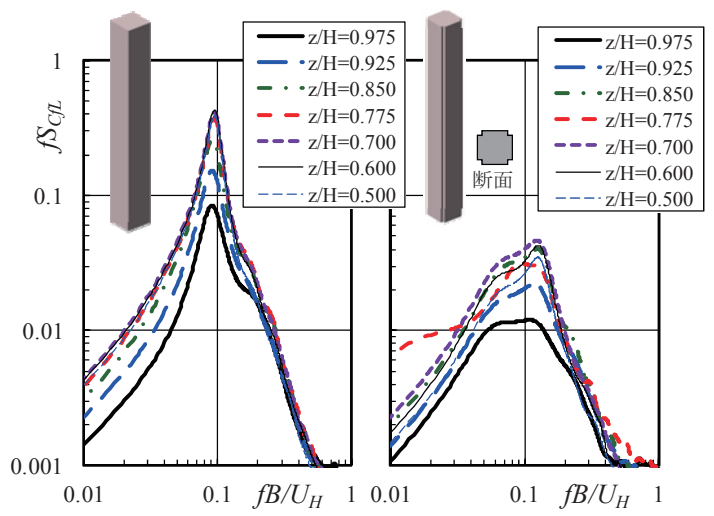

(a) (1)Square

(b) (7)Corner Cut
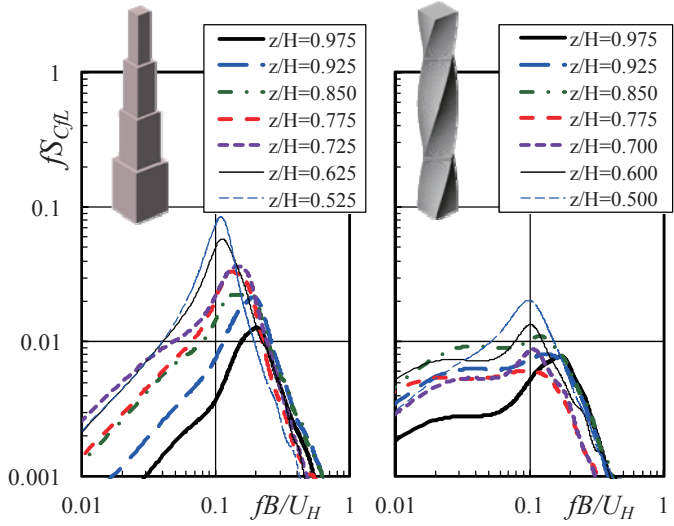

(c) (20)Setback

(d) (24) $180^{\circ}$ Helical Square

図4 風直交方向層風力のパワースペクトル密度

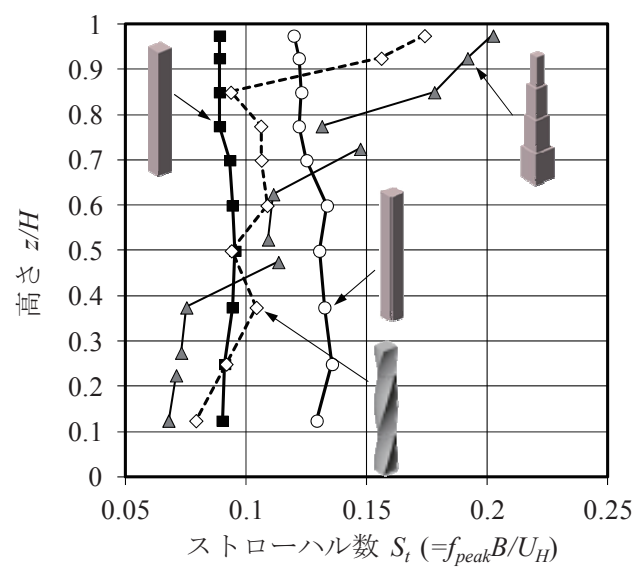

図 5 ストローハル数の鉛直分布 
ペクトル密度 $f S_{C L L}$ の例を図 4 に示す。また，そのパワー スペクトル密度より, 渦放出周波数であるストローハル 数成分 $S_{t}$ を算出し, その鉛直分布を図 5 亿示寸。

図 4(a)の(1)Square の各層風力係数のパワースペクトル 密度は, 各層において狭帯域のピークの高いスペクトル となり, 図 5 における(1)Square のストローハル数の高さ 方向の変化の小ささも考慮すると, 強く周期的なカルマ ン渦が高さ方向にほぼ一様に発生していることが伺える。 それに対して, 他の建物形状のパワースペクトル密度の ピーク值は, (1)Squareに比べると小さく, 広帯域に及ん でいるため, 周期的なカルマン渦の発生は抑制されてい ると推察される。また, 図 5 より, (20Setback や24180 180 Helical Square の高さ方向のストローハル数の変化は, (1)

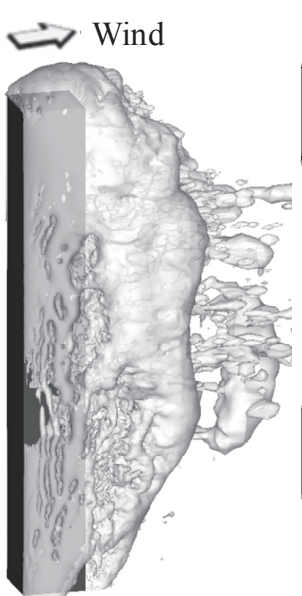

(a) 等値面表示

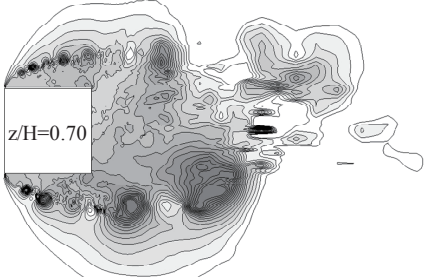

(b) $z / H=0.7$ の水平分布

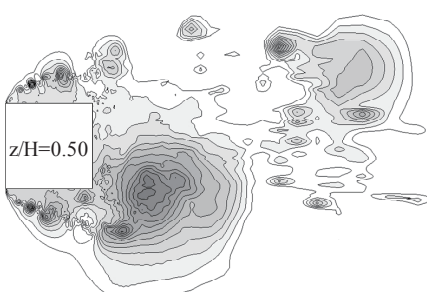

(c) $z / H=0.5$ の水平分布
図 6 (1)Square 周りの風圧係数分布(瞬時值)

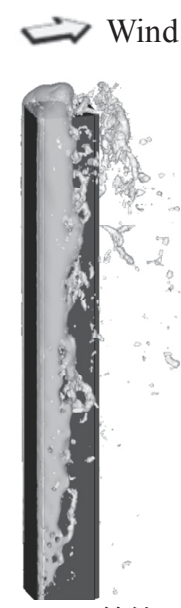

(a) 等值面表示

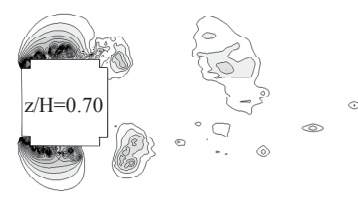

(b) $z / H=0.7$ の水平分布
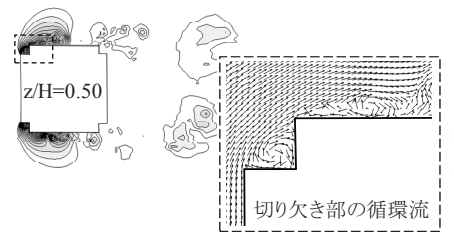

(c) $z / H=0.5$ の水平分布
図 7 (7) Corner Cut 周りの風圧係数分布之 切り欠き部の風の流れ(瞬時值)
Square や(7)Corner Cut に比べると大きく, 尖塔形状や螺 旋形状のように, 高さ方向に断面形状を変化させた建物 形状では, 渦の発生周波数が高さ方向で異なることが確 認できる。

これらの建物形状周りの渦放出の様子を可視化するた め, $\mathrm{CFD}$ (Computational Fluid Dynamics)により求めた風圧 係数の瞬時值を図 6〜図 9 に示寸。各図の(a)は風圧係数 の等值面を示しており, 3 次元的な渦構造が把握できる。 また, 各図の(b) と(c)は高さの異なる風圧係数の水平分布 を示しており, 図中の色の濃い部分ほど負圧が大きい領 域である。

図 6(b), (c)より, (1)Square では, 建物の側方と後方に周 期的なカルマン渦の洞列によると考えられる大きな負圧

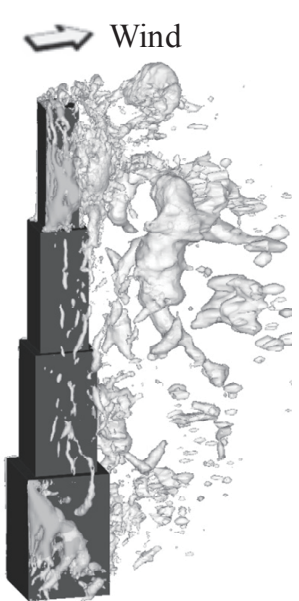

(a) 等值面表示

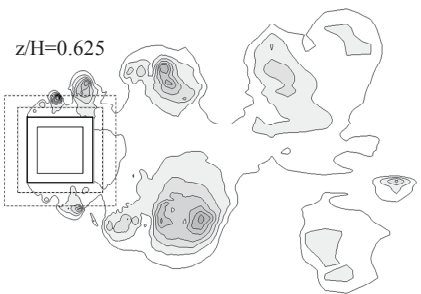

(b) $z / H=0.625$ の水平分布

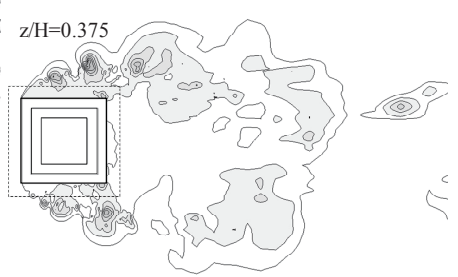

(c) $z / H=0.375$ の水平分布
図 8 (20Setback 周りの風圧係数分布(瞬時值) 
領域が確認でき，図 6(a)に見られるように，高さ方向で ほぼ一様に大きな洞構造が確認できる。このように建物 側面の上から下までほぼ同じタイミングでカルマン渦が 放出されるため, (1)Square では, 風直交方向に大きな加 振力が作用寸る。隅角部形状を工夫して空力特性を改善 した(7)Corner Cut 周りでも, 図 7(a)から, (1)Square と同 じように高さ方向に一様な渦構造が確認できるが, 放出 されている洞は(1)Square よりも小さく, 図 7(b), (c)の風圧 係数においても，大きな負圧領域は風上側の隅角部で生 じているのみである。これは, 図 7(c)に示した切久き部 の循環流が隅角部からの剥離を抑制し，大きな渦放出を 阻害しているためである。高さ方向に断面形状を変化さ せて空力特性を改善した(20) Setback と (24) $180^{\circ} \mathrm{Helical}$ Square の風力係数分布は, 図 8(b),(c)や図 9(c)で見られる ように, (1)Square と同じ断面であっても，その分布性状 は大きく異なる。また, 図 8(a) と図 9(a)に示される建物 形状の側方に放出されている渦は小さく, 高さ方向にき れいに揃った渦は見られない。この(20Setback や24180 $180^{\circ}$ Helical Square の渦構造の特徵は, 渦放出のタイミングが 高さ方向で異なっていることが要因であり(図 5), このよ うに高さ方向に断面形状が変化するような建物形状では, 側面に同時に作用寸る風力が小さいため空力特性が改善 される。

\section{4. 建物形状によるその他の特性変化}

4. 1 風摇れ居住性能の比較

80 階建てで, 20 階ごとにトラス階を有するセンターコ ア形式の超々高層建物の解析モデル ${ }^{19)}$ を用いて, 風応答 解析を実施し, 様々な建物形状の風摇れ居住性を評価し た結果を図 10 に示寸。図 10 では, 1 4 次の振動モード における全風向中の最大加速度を比較しており, 風の水 平振動に関する性能評価曲線 ${ }^{20}$ も併せてプロットしてい る。この性能評価曲線の右に示した数值は摇れを感じる 人の割合を示しており, H-30 はその摇れを体験した人の
30\%が摇れを知覚するということである。図 10 より，居 住性が優れている $90^{\circ} \mathrm{Helical}$ Square と $180^{\circ} \mathrm{Helical}$ Square の居住性能は, 1 次に対しては他の建物形態と同様に H-90 を超えるが, 2 次〜4次ではH-50程度となっている。

\section{2 周辺気流性状の比較}

高層建物周辺の風環境が，建物形状の影響を受けるこ とはよく知られており，隅切りなど建物隅角部の形状を 変えるなどによってビル風の対策とすることもある。図 11 は CFD による, 歩行者レベル(地上 $1.5 \mathrm{~m}$ )の平均風速 の増加領域を示した例であり ${ }^{21)}$, 色の濃い部分が, 超高 層建物の建設によって平均風速が大きく増加する領域を 示している。図11より, (1)Squareでは, 隅角部付近で風 速増加率が 1.8 以上の領域を示寸が，(7) Corner Cut や24) $180^{\circ}$ Helical Square では, 1.8 を超える領域は小さくなっ ている。ただし, (24 $180^{\circ}$ Helical Square の場合, 風速増加 率が 1.0 を超える領域は(1)Square の場合よりも広範囲に 及んでいる。また, 螺旋形状建物の周りでは, 角柱建物 の場合に比べて鉛直方向の風の流れが強くなることから 22)，都市の換気性状に影響を与える鉛直方向の風の道の 効果 ${ }^{23)}$ 考慮した場合, 建物形状の変化が建物周辺の環 境にも良い効果を与えることが期待される。

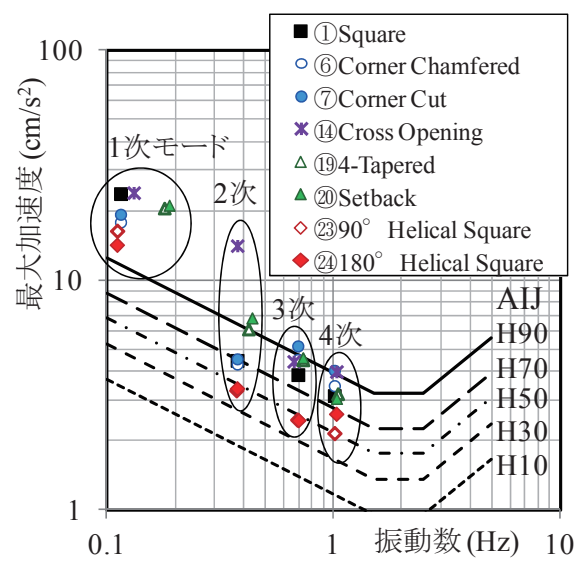

図 10 様々な建物形状の居住性評価

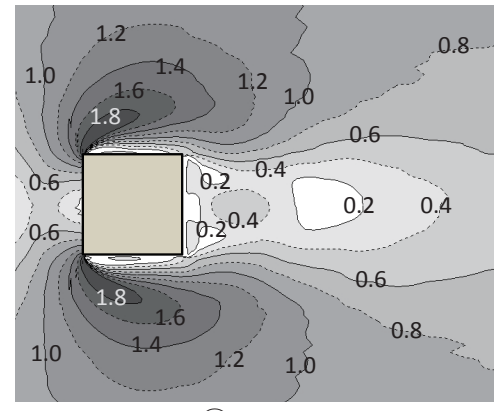

(1)Square

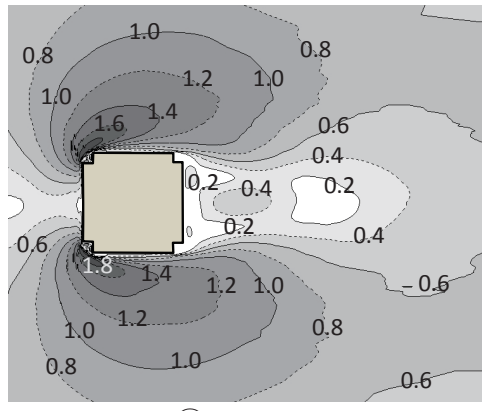

(7)Corner Cut

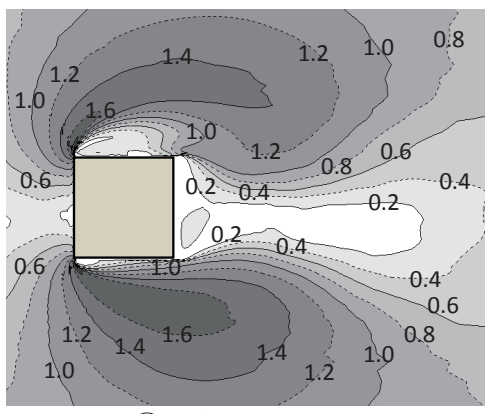

(24) $180^{\circ} \mathrm{Helical}$ Square

図 11 歩行者レベルの風速増加率 
5。まとめ

建物形状の変化による空力特性の改善が風荷重の大幅 な低減につながることから, 計画建物の形状検討は制震 装置の設置を考えるよりも前に，まず検討すべき価值が あると言える。また, 建物形状は, 超高層建物の安全性 だけでなく, 建物の風摇れ居住性や周辺環境に対しても 大きな影響を及ぼし，建物形状の変化によって，それら は総合的に改善される傾向を持つ。

参考文献

1）田村 幸雄, 中井政義, 大竹 和夫, 小鹿 紀英, 山脇 克彦, 人見 泰義,「新しい形態を有寸る超々高層建築物の耐風設 計手法に関寸る研究」, 国土交通省平成 $20 \cdot 21$ 年度建設技 術研究開発費補助金総合研究報告書, <http:/ www.mlit. go.jp/ tec/gijutu/kaihatu/josei/067houkoku.pdf $\$$, accessed 2012.10, (2010)

2) Tanaka, H., Tamura, Y., Ohtake, K., Nakai, M., Kim, Y. C., "Experimental investigation of aerodynamic forces and wind pressures acting on tall buildings with various unconventional configurations", Journal of Wind Engineering and Industrial Aerodynamics, Vol. 107-108, pp. 179-191,(2012)

3）田中英之, 田村幸雄, 大竹和夫, 中井政義, 金容徹, 「新しい形態老有する超々高層建築物の空力特性」, 日本建 築学会構造系論文集, 第 77 巻, 第 678 号, pp. 1211-1218, (2012)

4) Kumar, B. E, Tamura, Y., Yoshida, A., Kim, Y. C., Yang, Q., "Local and total wind force characteristics of triangular-section tall buildings", Proceedings of The 22nd National Symposium on Wind Engineering, pp. 179-184, (2012)

5) Hayashida, H., and Iwasa, Y., "Aerodynamic shape effects on tall building for vortex induced vibration", Journal of Wind Engineering and Industrial Aerodynamics, Vol. 33(1-2), pp. 237-242,(1990)

6) Hayashida, H., Mataki, Y. and Iwasa, Y., "Aerodynamic damping effects of tall building for a vortex induced vibration", Journal of Wind Engineering and Industrial Aerodynamics, Vol. 43(3), pp. 1973-1983,(1992)

7) 白石 成人, 松本 勝, 白土 博通, 石崎浩, 長田 信, 松井 俊彦,「隅切りによる矩形断面の空力安定化効果」, 第9 回風工学シンポジウム論文集, pp. 193-198, (1986)

8) Kwok, K.C.S., Wilhelm, P.A. and Wilkie, B.G., "Effect of Edge Configuration on Wind-induced Response of Tall Buildings", Engineering Structures, Vol. 10, pp. 135-140, (1988)

9) Miyashita, K., Katagiri, J., Nakamura, O., Ohkuma, T., Tamura, Y., Itoh,M. and Mimachi, T., "Wind-induced Response of High-rise Buildings", Journal of Wind Engineering and Industrial Aerodynamics, Vol. 50, pp. 319-328,(1993)

10) 天野 輝久,「一様流中における三次元正四角柱の渦励 振及びギャロッピングに及ぼす隅欠き・隅切りの効果」,
日本建築学会構造系論文集, 第 478 号, pp. 63-39, (1995)

11) Kawai, H., "Effect of comer modifications on aeroelastic instabilities of tall buildings", Journal of Wind Engineering and Industrial Aerodynamics, Vol. 74-76, pp. 719-729, (1998)

12) Cooper, K. R., Nakayama, M., Sasaki, Y., Fediw, A. A., Resende-Ide, S., Zan, S. J., "Unsteady aerodynamic force measurements on a super-tall building with a tapered cross section", Journal of Wind Engineering and Industrial Aerodynamics, Vol. 72, pp. 199-212,(1997)

13) Kim, Y. M., and You, K. P., "Dynamic responses of a tapered tall building to wind load", Journal of Wind Engineering and Industrial Aerodynamics, Vol. 90, pp. 1771-1782, (2002)

14) Kim, Y. M., and You, K. P., Ko, N. H., "Across-wind Response of an Aeroelastic Tapered Tall Building", Journal of Wind Engineering and Industrial Aerodynamics, Vol. 96, pp. 1307-1319,(2008)

15) Kim. Y. C., Kanda,J., "Characteristics of aerodynamic forces and pressures on square plan buildings with height variations", Journal of Wind Engineering and Industrial Aerodynamics, Vol. 98, pp. 449-465, (2010)

16) Kim. Y. C., Kanda, J., "Effects of taper and set-back on wind force and wind-induced response of tall buildings", Wind and Structures, Vol. 13, No. 6, pp. 499-517, (2010)

17) Dutton, R., Isyumou, N., "Reduction of tall building motion by aerodynamic treatments", Journal of Wind Engineering and Industrial Aerodynamics, Vol. 36, pp. 739-747, (1990)

18) 大竹和夫, 田村幸雄, 田中英之, 中井政義, 小鹿紀英, 鈴木 芳隆、「新しい形態老有寸る超々高層建築物の風外力 に関寸る研究 (その 3)螺旋形状建築物の風店答特性」, 日 本建築学会大会学術講演梗概集, D1, pp. 143-144,(2010)

19) 阿部 雅史, 小鹿 紀英, 鈴木 芳隆, 山脇 克彦, 人見 泰義, 五十嵐 信哉,「新しい形態を有寸る超々高層建築物の振動 性状に関する研究」, 日本建築学会大会学術講演梗概集, B1, pp. 905-906, (2010)

20) 日本建築学会, 「建築物の振動に関する居住性能伻価指針・ 同解説」,(2004)

21）田中 英之, 大竹和夫, 土屋 直也, 「螺旋形状高層建物周 辺の風環境, 日本風工学会誌, 第38巻, 第2 号, pp. 123-124, (2013)

22) 田中 英之, 大竹和夫, 士屋 直也, 「超高層建築物周辺の 流孔特性, 第 25 回数值流体力学シンポジウム講演了稿集, (2011)

23 義江 龍一郎, 田中 英之, 白澤 多一, 小林 剛, 「高層密集 市街地における建物群の形態が歩行者レベルの風速·気温 分布に与える影響」, 日本建築学会環境系論文集, 第 73 巻, 第627 号,pp. 661-667,(2008) 